Article

\title{
The Interdependence of Debt and Innovation Sustainability: Evidence from the Onset of Credit Default Swaps
}

\author{
Yixin Chen * and Junrui Zhang \\ Department of Accounting and Finance, School of Management, Xi'an Jiaotong University, Xi'an 710049, China; \\ zhangjr@xjtu.edu.cn \\ * Correspondence: chenyixin0408@stu.xjtu.edu.cn
}

Received: 27 April 2019; Accepted: 21 May 2019; Published: 23 May 2019

check for updates

\begin{abstract}
Innovation sustainability requires sustainable financing. Extensive research suggests that debt is a disfavored source of innovation financing. In this study, we show that a recent financial development, credit default swaps (CDSs), may change the institutional logics of debt, making debt useful to the financing innovation. To be specific, we find that with CDS protection, creditors become less concerned with a borrowing firm's credit risk and risk taking, making debt tolerant of early failures and reducing the negative impact of debt on the process of Innovation. In addition, we find that the availability of CDSs is more likely to change the nature of long-term debt than that of short-term debt, making long-term debt a useful instrument for the financing of innovation. Finally, the mitigation effect of CDS on the relation between debt and innovation is more pronounced for CDS firms with higher pay sensitivity to stock price volatility $(\mathrm{Veg} a)$ and less financial constraints, revealing that a CEO's incentive, rather than the relaxed financing constraints, is the underlying channel for the reduced negative impact of debt on innovation after CDS trading.
\end{abstract}

Keywords: R\&D intensity; innovation; credit default swaps; debt financing; sustainability

\section{Introduction}

Sustainable growth in firms' profits depends on a lot of factors, of which business conceptions and innovation are of great significance [1-3]. Innovation is even regarded as the key driver of a nation's economic sustainable development [4]. However, in reality, innovative firms face serious financing frictions, which lead to credit rationing, increased cost of capital, and a suboptimal level of innovation investment. How to help innovative firms mitigate their financing frictions has become an important question for the sustainability of a society, and has received much attention from academic researchers [5]. In this paper, we study whether and how a financial instrument innovation, credit default swaps (CDSs), helps firms to use debt as a financing source of sustainable innovation investments.

As an important source of finance, debt has been playing critical roles in corporate investments; however, debt is usually believed to be a disfavored source of finance for innovation investment. Extensive research has suggested that innovation investments have certain characteristics, such as uncertain payoffs and limited collateral value that make debt a poor financing instrument for innovation [5-7]. Yet, debt is one of the major sources of sustainable financing, and the size of the debt market is much larger than the total amount of retained earnings or the size of the equity market. The fiscal and welfare costs of high levels of debt are small in an economy where safe interest is less than the growth rate [8], so avoiding debt would be counterproductive. Gaining access to sustainable debt financing still remains important for all innovative firms.

The main issue for innovative firms is that they need to provide collateral to secure a loan. Tradable patents are one of the most common forms of collateral used to obtain debt financing. 
Recent studies document that some firms can better use debt to finance innovation, especially when they have tradable patents [9-11]. However, only a limited number of innovative firms have tradable patents or are willing to use their patents as collaterals to obtain debt financing. The natural question here is whether the use of tradable patents as collateral is the only way to obtain debt financing for $R \& D-i n t e n s i v e$ firms. In other words, are there any other ways through which debt can become more useful in innovation financing? In this study, we investigate a new mechanism through which debt can be more accessible to the financing of innovation.

We identify the roles of credit default swaps (CDSs) in facilitating the use of debt in the financing of innovation. A CDS contract represents a new financial instrument innovation that allows creditors to buy insurance from a third party to insure against debtor defaults, enabling creditors to hedge credit risks and receive default payments when the debtors go bankrupt (CDSs represent a financial innovation that allow creditors to hedge and transfer credit risks. After making a loan to a firm, a creditor can enter into a CDS contract with a CDS seller, which charges an insurance premium to insure the creditor against credit risks. Within a CDS contract, the creditor avoids credit risks, while the CDS seller bears the credit risks in exchange for an insurance premium. By reallocating risks, CDSs complement the debt market, and therefore play an important role in debt financing $[12,13]$. Some may be confused about the difference between CDS and CDO (Collateralized Debt Obligation). CDOs represent claims on an underlying pool of risky debt instruments, such as corporate bonds or mortgage loans. In the securitization process, exposure to the default risk that is inherent in the securities placed in the pool is split up among different CDO tranches that are created, with buyers of the riskiest equity and mezzanine tranches bearing most of it. These investors may end up losing most or even all of their principal value. However, this risk is comparable to the risk on a bond-the investor cannot lose more than was invested initially. By contrast, a credit default swap is like an insurance contract). Therefore, the availability of CDSs on a firm's loan makes creditors more willing to make loans to the firm, even if the firm does not have sufficient collaterals for debt [12-15]. Furthermore, the existence of CDSs changes the institutional logic of debt and the relation between debtors and creditors. With CDS protection, creditors are less affected by financial condition of debtor, since the CDS sellers cover the loss during a credit event. Therefore, the trading of CDSs may have significant impact on the compatibility between debt and the financing of innovation.

In this study, based on a sample of publicly listed firms, by exploiting the variation in timing of CDS trading initiation, we use a difference-in-differences model to examine whether and how the trading of CDSs changes the relation between a firm's debt level and its investment in innovation. To address the concern that the onset of CDS trading could be endogenous to the innovation, in addition to using the firm-fixed effect to control for time-invariant unobserved firm characteristics, we employ a propensity score matching analysis and two-stage instrumental variable regressions to control for the endogeneity of CDS introduction.

Our paper contributes to the literature in the following ways. First, we extend the literature examining the relation between debt financing and corporate innovation. Specifically, we find that CDSs may have turned debt from an instrument that is unforgiving for failures into one that is tolerant for small failures, thereby changing its role in the financing of innovation. Second, our paper contributes to the ongoing debate on the impact of CDS trading. Our research suggests that CDS contracts can facilitate the compatibility between debt and the financing of innovation, promote firms' innovative activities, and eventually encourage economic sustainable growth. Lastly, we reveal the channel through which CDS changes the relation between debt and innovation. By demonstrating that the effects of CDS on the relation between debt and innovation are stronger for firms with higher pay sensitivity to stock price volatility (CEO incentive structure channel), we extend the literature by showing that the incentive structure channel is the underlying channel through which CDS matters.

The remainder of the paper proceeds as follows. Section 2 develops hypotheses, relying on insights from the literature review. Section 3 describes the data sources, defines variables, and provides empirical designs. Section 4 presents and discusses our baseline results and addresses endogeneity 
issues. Section 5 provides the major possible channels for the effects of CDS trading on the financing of innovation. Section 6 provides more robustness checks, while Section 7 concludes and discuss the main results.

\section{Literature Review and Hypothesis Development}

In this section, we review three strands of literature: literature on innovation and sustainable development, recent studies on the link between debt and the financing of $R \& D$, and studies on the CDSs. Based on those insights from the prior literature, we formulate hypotheses in our study.

\subsection{Innovation and Sustainable Development}

The concept of "sustainability" originated in the context of renewable resources. In 1980, the International Union for the Conservtion of Nature and National Resources (IUCN) brought the term "sustainable development" into prominence with its World Conservation Strategy (WCS), in an "attempt to carry the concept of sustainability beyond simple renewable resources system" [16]. In 1987, the famous report "Our Common Future" defined the term as "development that meets the needs of current generations without compromising the ability of future generations to meet their needs and aspirations" [17]. Today, sustainable development is an integration of economic, social, and environmental issues. When it comes to an economics context, sustainability refers to "the process whereby the real per capita income of a country increases over a long period of time" [18].

Extensive studies confirm the importance of innovation in sustainable economic growth. Endogenous growth models emphasize that technological progress, which occurs through innovation, is the main driver of sustainable economic growth $[19,20]$. Porter [21] argues that "to compete effectively in international markets, a nation's businesses must continuously innovate and upgrade their competitive advantages. Innovation and upgrading come from sustained investment in physical as well as intangible assets". In his seminal paper, Barney [22] distinguishes the concepts of "competitive advantage" and "sustained competitive advantage". According to him, innovation can provide a firm with sustained competitive advantage because its' competitors cannot easily replicate it. Recent empirical studies confirm the significant role of innovation for firms' sustainable development $[23,24]$. Given the importance of innovation for a firm's and nation's sustainable development, it is a priority to mitigate the financing frictions of corporate innovation.

\subsection{Debt and the Financing of Innovation}

Modigliani-Miller theorem posits that in a perfect capital market, where there are no taxes, transaction costs, or information asymmetry, the market value of a firm is irrelevant of its capital structure [25]. Consequently, equity and debt capital should be indifferent as a financing source for a firm's investments. However, perfect market does not exist in reality. Empirical studies show that a firm's market value changes significantly in response to changes in the capital structure [26-31]. These studies reject the propositions of the MM theorem based on some kind of market imperfection, suggesting that it should not be indifferent for a firm when selecting equity or debt to finance its investments.

In the context of financing innovation, debt can be disfavored by both creditors and firms. While investments in innovation can lead to upside gains, they also tend to be related to significant downside risk [32]. From the creditor's perspective, they are exposed to the borrowing firm's downside default risk but cannot enjoy the borrowing firm's upside gains. Consequently, creditors are less willing to make loans to the projects that engage in substantial Innovation. If they make loans, they may place constraints on the borrowing firms by constraining indebted firms from carrying out additional innovation and may be active in monitoring downside risks [33]. As a result, debt is conventionally believed to be a poor financial instrument for the financing of innovation [5-7].

From the firm's perspective, they usually need to maintain a certain level of cash reserves to pay for the related debt servicing costs. While substantial capital investments in innovation are 
essential to achieving productivity, paying out a stable cash flow periodically to creditors will make success in R\&D more difficult due to the need for periodic payment on the debt. For this reason, firms may be unwilling to use debt financing to engage in those risky investments, such as innovation investment. Therefore, we may see that a firm's debt level is negatively associated with its innovation and we hypothesize:

Hypothesis 1. A firm's debt is negatively associated with its innovation.

\subsection{Credit Default Swaps and the Changing Institutional Logic of Debt}

Since the credit crisis of 2007-2009, CDSs have come under intense criticism as being a major threat to the systemic stability. Many contend that single-name CDSs are a source of potential interconnectedness and systematic risk across financial institutions that could serve as a transmission mechanism for contagion in the event of a systemic financial disruption [34]. Stout regards Congress's passage of Commodity, which made derivatives legally enforceable, as the root of the crisis and calls for strict regulation over the CDS market [35]. George Soros, the famous hedge fund manager, even called for an outright ban of CDS trading [36]. In contrast, Stulz [37] made a detailed survey of the role of CDS during the financial crisis and argues that the wrongful expectation of real estate prices and high levels of leverage of financial institutions are the main causes of the crisis, while CDS should not be. In a recent survey by Culp et al. [38], they found no significant empirical evidence indicating that single-name CDSs are a major threat to systematic stability. It is clear that both benefits and costs coexist in the context of CDS trading. Our study investigates the potentially beneficial impact of CDS trading on cooperate debt financing of innovation activities.

Based on the recent literature examining the effects of CDS trading on reference firms' financial policies, we posit that CDS can positively facilitate the firms' debt financing of innovation for the following reasons. First, CDS changes the nature of debt financing and may help relax the capital constraint on firms [14,39]. A CDS contract is simply a financial insurance that allows creditors to transfer the credit risk on the loans to CDS sellers. If a pre-specified credit event occurs, creditors receive a payment from CDS sellers. With such protection, creditors become less concerned with a borrowing firm's risk profile and risk taking and are more willing to lend. In other words, creditors with CDS protection will be less negatively affected by the risks in R\&D, and they may reduce monitoring on the borrowing firms, giving firms more freedom in carrying out innovation. In line with this argument, Saretto and Tookes [40] find empirical evidence that CDS firms experience fewer supply-side friction in lending after CDS initiation. By reallocating risk bearing, CDSs may have turned debt from an unforgiving instrument into an instrument that is more likely to tolerate risk taking, experimentation, and early failure.

Second, CDS initiation can affect CEO compensation structure and make managers more willing to use debt to finance Innovations. After the onset of CDS trading, debt-holders' incentives to monitor the borrowing firms are significantly reduced due to the transfer of credit risk [41]. In response to the reduced creditors' monitoring after CDS trading, the board of directors are more likely to increase risk-taking incentives in CEO compensation packages to better align managerial incentives with the interests of shareholders. Unlike debt-holders, shareholders can enjoy the upside return of their risk taking. In other words, debt is normally involved with fixed payments, and firms that succeed in innovation do not share their rewards with creditors. Therefore, the stronger risk-taking incentives in compensation can eventually heighten managers' incentives to innovate using debt.

In summary, the channel of either expanded credit supply or increased risk-taking incentive in compensation packages implies that the onset of CDS trading weakens the tension between debt and R\&D (innovation). With CDSs, creditors become more willing to lend, contributing to the debt financing of innovation. CDSs may alter the risk-taking incentive of CEO compensation and make the managers more willing to use debt to finance innovation. Hence, we hypothesize: 
Hypothesis 2. The onset of CDS trading reduces the negative association between a firm's debt and its innovation.

\subsection{Long-Term Debt vs. Short-Term Debt}

Although the onset of CDS trading may change the institutional logic of debt, it is more likely to change the institutional logic of long-term debt than that of short-term debt. Short-term debt is "short-term" by its nature, and has to be paid back in the short run, even after the trading of CDSs. Firms with high levels of short-term debt may still be tied with the financial constraints to pay back the loan in the short-term and are unable to invest in innovation, regardless of whether with CDS trading or not. Therefore, the trading of CDSs on a firm's debt is more likely to make long-term debt rather than short-term debt useful to the financing of innovation. Therefore, we hypothesize:

Hypothesis 3. The onset of CDS trading has a stronger impact on the relation between long-term debt and innovation than on the relation between short-term debt and innovation.

\section{Methodology}

In this section, we describe our sample selection process and data sources, variable definitions, OLS (Ordinary Least Square) model specification, and summary statistics. Table 1 lists the detailed definitions of variables.

Table 1. Definitions of Variables.

\begin{tabular}{|c|c|}
\hline Variable & Definition \\
\hline RDS & $\begin{array}{l}\text { Research and development expenses of firm } i \text { in year } t \text { scaled } \\
\text { by its total sales in year } t .(\mathrm{xrd} / \mathrm{sale})\end{array}$ \\
\hline LnPatent & $\begin{array}{l}\text { The natural logarithm of one plus patent count of firm } i \text { in year } \\
\text { t. }(\operatorname{Ln}(1+\text { npat }))\end{array}$ \\
\hline Trading & $\begin{array}{l}\text { A dummy variable, equals } 1 \text { if firm } i \text { has active CDS trading by } \\
\text { year } t \text {, and } 0 \text { otherwise. }\end{array}$ \\
\hline Debt & $\begin{array}{l}\text { Book debt, defined as total liabilities plus preferred stock } \\
\text { minus deferred taxes and convertible debt divided by total } \\
\text { book assets at the end of year } t \text {. (lt }+ \text { pstkl }- \text { txditc }- \text { dcvt)/at }\end{array}$ \\
\hline Debt_S & $\begin{array}{l}\text { Short-term debt, measured as short-term debt divided by total } \\
\text { book assets at the end of year } t \text {. (dlc/at) }\end{array}$ \\
\hline Debt_L & $\begin{array}{l}\text { Long-term debt, measured as long-term debt divided by total } \\
\text { book assets at the end of year } t \text {. (dltt/at) }\end{array}$ \\
\hline VegaT & $\begin{array}{l}\text { (Black-Scholes Vega of all current option grants }+ \\
\text { Black-Scholes Vega of all prior option grants) } \times 0.01\end{array}$ \\
\hline VegaC & Black-Scholes Vega of all current option grants $\times 0.01$ \\
\hline KZindex & $\begin{array}{l}\text { KZindex }=-1.001909 \times(\mathrm{ib}+\mathrm{dp}) / \text { lagged ppent }+0.2826389 \times \\
(\mathrm{at}+\text { prcc_f } \times \text { csho-ceq-txdb)/at }+3.139193 \times(\mathrm{dltt}+\mathrm{dlc}) /(\mathrm{dltt}+ \\
\mathrm{dlc}+\text { seq })-39.3678 \times(\mathrm{dvc}+\mathrm{dvp}) / \text { lagged ppent }-1.314759 \times \\
\text { che/lagged ppent }\end{array}$ \\
\hline MTB & $\begin{array}{l}\text { Market to book ratio, defined as total assets plus market value } \\
\text { of common equity minus book equity all over total assets at the } \\
\text { end of year } t \text {. (at }+ \text { prcc_f } \times \text { csho-ceq)/at }\end{array}$ \\
\hline LNTA & $\begin{array}{l}\text { Total assets, measure as the natural log of total assets at the end } \\
\text { of year } t .(\log (a t))\end{array}$ \\
\hline Tangibility & $\begin{array}{l}\text { Measured as Net property, plant, and equipment of firm } i \text { in } \\
\text { year } t \text { divided by its Total Assets in } t \text {. (ppent/at) }\end{array}$ \\
\hline Profitability & $\begin{array}{l}\text { Calculated as earnings before interest, depreciation, taxes, } \\
\text { and amortization of firm } i \text { in year } t \text { divided by total assets in } \\
\text { year } t \text {. (ebit/at) }\end{array}$ \\
\hline HHI & $\begin{array}{l}\text { Sales based Herfindahl index of four-digit SIC industry } j \text { to } \\
\text { which firm } i \text { belongs, measured at the end of year } t \text {. }\end{array}$ \\
\hline HHI2 & The squared term of HHI \\
\hline
\end{tabular}




\subsection{Data and Sample Selection}

The data for this study comes from three main sources: The Bloomberg Terminal for CDS data, The MIT-IU database for our patent data, and the COMPUSTAT, a financial information database provided by Standard \& Poor's Financial Services LLC located in New York, for financial data. Specifically, we identify US firms that have single-name 5-year CDS between January 2001 and January 2011 from Bloomberg terminal. See Appendix A for a sample CDS contract. Then, we merge CDS data and financial data using 8-digit CUSIP (Committee on Uniform Securities Identification Procedures). All firm financial data are retrieved from COMPUSTAT. Patent data are extracted from the MIT-IU (Massachusetts Institute of Technology-Indiana University) data and are sorted by CRSP (Center for Research in Security Prices) permno and application year. The MIT-IU patent data provides information for all patent granted by US Patent and Trademark Office between 2001 and 2010. We link patent data to financial data using CCM link table.

Consistent with common practice [42], we exclude financial and utility firms (SIC codes 6000-6999 and 4900-4999). Firm-years with missing data on any of the variables are deleted as well. The final sample consists of 329 CDS firms for 3125 firm-year observations, 6220 non-CDS firms for 36,363 firm-year observations, and total 39,488 firm-year observations.

\subsection{Variables}

We construct two variables to measure innovation input and output, respectively. Following Chen and Miller [42], we use R\&D intensity (RDS), calculate $\mathrm{d}$ as total R\&D expenditures divided by sales revenue, to stand for innovation input. In line with the literature $[43,44]$, firm-years with missing $R \& D$ expenditures are assigned zero. We eliminate observations with R\&D intensity higher than 1 to make sure that the sample firms are more comparable with each other in innovation activities [42].

The variable to measure innovation output is patent count, defined as the total number of patents filed (and eventually granted) in a given year. Because there is an average time lag of two to three years between patent application and grant [45], we use application year, which better reflects the actual time when innovation activities take place [46]. Consistent with the literature [43,44], firm-years with missing values on patent count are assigned zero. We use the natural logarithm of one plus patent count (LnPatent) to measure innovation output to reduce the skewness of patent count.

We construct three variables to measure a firm's debt. We use a firm's leverage ratio (Debt), defined as total debt (short-term debt plus long-term debt) divided by total assets, to measure a firm's total debt level. The second one is long-term debt (Debt_L), defined as total long-term debt divided by total assets. The third one is short-term debt (Debt_S), measured as total current, short-term debt divided by total assets.

Following Ashcraft and Santos [47], Saretto and Tookes [40], and Subrahmanyam et al. [48,49], we define CDS Trading (Trading) as one, for a CDS firm, after the inception of the firm's CDS trading, and zero otherwise. This indicator variable, Trading, allows us to exploit the impact of the CDS trade inception of a firm on the relation between debt and innovation.

To isolate the effect of CDS trading on the relation between debt and innovation, we control for a variety of firm and industry characteristics that have been proved as significant innovation determinants [50]. All variables are computed for firm $i$ over its fiscal year $t$. Ziedonis and Hall [51] finds that large and capital-intensive firms file for more patents. Thus, we include the log transformation of total assets (LNTA) to control for firm size and use net property, plant, and equipment divided by total assets (Tangibility) to account for capital intensity. We include (Profitability), which equals earnings before interest and taxes divided by total assets, to control for operating profitability. To control for growth opportunity, we include market to book ratio (MTB), which equals market value of assets divided by the book value of assets. Following Aghion et al. [52], we control for industry concentration using the sales Herfindahl index (HHI) constructed at the four-digit SIC level. We control for the nonlinear effects of industry concentration using the squared term of Herfindahl index (HHI2). Detailed definitions of the variables are shown in Table 1. 


\subsection{Model Specification}

Following Martin and Roychowdhury [41], Ashcraft and Santos [47], and Subrahmanyam, Tang, and Wang [48], we use a difference-in-differences method to investigate the effect of CDS trading on the relation between debt and innovation. Specifically, we include an interaction term of debt and CDS trading in our model, whose coefficient reflects the incremental association between debt and innovation after the inception of CDS trading. We estimate the following model to examine the hypotheses using ordinary least square regression:

$$
\begin{aligned}
\mathrm{Y}_{\mathrm{i}, \mathrm{t}+\mathrm{n}=} & \beta_{0}+\beta_{1} \text { Debt }_{\mathrm{i}, \mathrm{t}}+\beta_{2} \text { Debt }_{\mathrm{i}, \mathrm{t}} \times \text { Trading }_{\mathrm{i}, \mathrm{t}}+\beta_{3} \text { Trading }_{\mathrm{i}, \mathrm{t}}+\beta_{4} \text { Controls }_{\mathrm{i}, \mathrm{t}}+\text { Year Effect }_{\mathrm{t}} \\
& + \text { Firm Effect }_{\mathrm{i}}+\text { error }_{\mathrm{i}, \mathrm{t}}
\end{aligned}
$$

In model (1), $i$ indexes firm, $\mathrm{t}$ indexes time, and $\mathrm{n}$ indexes zero or one. $\mathrm{Y}$ stands for innovation input (RDS) and output (LnPatent) variables, respectively. Since there is a time lag between innovation input and output, we use the LnPatent in the subsequent one year and RDS in the current year [44] (our regression results are robust to using LnPatent in the subsequent two or three years). Other variables are defined in Section 3.2. We include year- and firm-fixed effects to control for time-invariant and firm-invariant omitted variables that may affect innovation, respectively. The firm-fixed effect controls the intrinsic difference between CDS firms and non-CDS firms. Because RDS and LnPatent are likely to be autocorrelated over time, we cluster standard errors by firm [53]. All of the continuous variables are winsorized at $1 \%$ and $99 \%$ to minimize the effect of extreme values on regression results. Following Aiken et al. [54], the continuous variables used in interaction terms are mean-centered to mitigate multi-collinearity problem.

\section{Results}

In this section, we first provide the summary statistics of the main variables. Then, we examine the effect of the onset of CDS trading on the relation between debt and innovation. Then, we investigate the differential impact of CDS trading on the relation between long-term, short-term debt, and innovation. Next, we address endogeneity issues by using propensity score matching method and instrumental variable approach. Finally, we identify the channels through which the CDSs trading affects the relation between debt and R\&D (innovation).

\subsection{Summary Statistics}

Panel A of Appendix B reports the descriptive statistics of the main variables. The entire sample consists of 39,488 firm-year observations. Comparable to previous studies [42,44], the mean values of RDS and LnPatent are 0.06 and 0.51, respectively. The mean value of Debt is 0.21 , of which long-term debt is $17 \%$ and short-term debt is $4 \%$. The summary statistics of other variables are consistent with the existing literature [11]. Panel B of Appendix B reports both Pearson and Spearman rank correlations of main variables. Lower-triangular cells report Pearson's correlation, while the upper-triangular cells present Spearman's rank correlation. Consistent with previous literature, debt (Debt), short-term debt (Debt_S), and long-term debt (Debt_L) are all negatively associated with innovation input (RDS) and output (LnPatent).

\subsection{Baseline Regression}

The baseline regression results are reported in Table 2. Columns (1) and (2) presents the regression results on R\&D intensity and patent count, respectively. In both columns, the coefficients on debt are negative and significant ( $t$-statistics $=-3.00$ for $R \& D$ and -2.62 for patent), suggesting that a firm's debt is negatively associated with its innovation. These finding are consistent with our Hypothesis 1. 
Table 2. Baseline Results.

\begin{tabular}{ccc}
\hline Variables & $\mathbf{( 1 )}$ & $\mathbf{( 2 )}$ \\
\hline & RDSt & LnPatent $(t+1)$ \\
Debt & $-0.425^{* * *}$ & $-0.086^{* * *}$ \\
& $(-3.00)$ & $(-2.62)$ \\
Trading & $0.179^{* *}$ & $0.851^{* * *}$ \\
& $(2.38)$ & $(2.70)$ \\
LNTA & $0.042^{* *}$ & $-0.465^{* * *}$ \\
& $(1.69)$ & $(-6.70)$ \\
Tangibility & $0.116^{* * *}$ & $0.107^{* * *}$ \\
& $(3.13)$ & $(8.66)$ \\
Profitability & -0.327 & $0.166^{* *}$ \\
& $(-1.38)$ & $(2.35)$ \\
MTB & $-0.940^{* * *}$ & $-0.037^{* *}$ \\
& $(-5.53)$ & $(-2.13)$ \\
HHI & 0.013 & 0.004 \\
& $(0.98)$ & $(1.59)$ \\
HHI2 & 0.417 & $0.956^{* * *}$ \\
& $(1.16)$ & $(3.27)$ \\
Constant & -0.302 & $-0.817^{* * *}$ \\
Firm FE & $(-1.04)$ & $(-2.60)$ \\
Year FE & -0.117 & -0.102 \\
Adj-R2 & $(-0.49)$ & $(-1.22)$ \\
YES \\
YES & YES \\
YES & 39,488 \\
& 39,488 & 0.759 \\
\hline
\end{tabular}

Note: This table presents the regression results of the impact of CDS trading on the association between debt and innovation using Equation (1). Variable definitions are shown in Table 1. In column (1), the dependent variable is R\&D intensity. In column (2), the dependent variable is patent count. T-statistics in parentheses are calculated based on standard error clustered by firm and robust to heteroscedasticity; ${ }^{*}, * *$, and ${ }^{* * *}$ denote significance at $10 \%, 5 \%$, and $1 \%$ level using two-tailed $t$-tests, respectively.

Furthermore, the coefficients on the interaction term of debt and CDS trading (Debt $\times$ Trading) are positive and significant ( $\mathrm{t}$-statistics $=2.38$ for $\mathrm{R} \& \mathrm{D}$ and 2.70 for patent), suggesting the onset of CDS trading reduces the negative association between a firm's debt and its innovation. In response to the reduced monitoring by creditors and increased risk-taking incentives in CEO compensation package, firms are more likely to use debt to finance innovative activities after CDS introduction, which is in line with our Hypothesis 2.

With regard to control variables, our regression results are largely consistent with prior studies. The coefficients on LNTA in all models and the coefficient on Tangibility in model (2) are positive and significant. Consistent with Aghion et al. [52], we find an inverted-U shape relation existing between product market competition and innovation output. The coefficients on Profitability in model (1) and (2) suggest that more profitable firms are less likely to innovate.

\subsection{Conditional Effect of Debt Term}

Our Hypothesis 3 predicts that CDS trading has a stronger impact on the relation between long-term debt and innovation than on that between short-term debt and innovation. To examine this hypothesis, we construct two interaction terms: short-term debt and CDS trading (Debt_S $\times$ Trading), and long-term debt and CDS trading (Debt_L $\times$ Trading), and replace the interaction term of debt and CDS trading in Equation (1) with these two new terms, respectively. In addition, following Stohs and Mauer [55] and Ozkan [56], we include a series of debt structure determinant variables in our model: Signaling, defined as the difference between the earnings in year $t+1$ and $t$, divided by earnings in year $t$; Asset maturity, defined as the ratio of net property, plant, and equipment to annual depreciation expense; Taxes, defined as the ratio of income tax expense to pretax income. Then, we re-estimate Equation (1) to obtain the regression results. 
The regression results are presented in Table 3. Columns (1) and (2) list the results of short-term debt regression. As predicted, the coefficients on the interaction term of short-term debt and CDS trading are both insignificant ( $\mathrm{t}$-statistics $=1.33$ for $\mathrm{R} \& \mathrm{D}$ and 0.51 for patent). However, in columns (3) and (4), both of the coefficients are positive and significant ( $t$-statistics $=1.68$ for $R \& D$ and 2.64 for patent). These results indicate that the effect of CDS trading on the association between debt and innovation is more pronounced for long-term debt than for short-term debt. Firms with high levels of short-term debt are more concerned with financial distress cost. Maintaining substantial capital investment level in innovations becomes more difficult for them due to the need of periodic payment on the debt. The results in Table 3 support our Hypothesis 3.

Table 3. Conditional Effect of Debt Term.

\begin{tabular}{|c|c|c|c|c|}
\hline Variables & (1) & (2) & (3) & (4) \\
\hline \multirow{3}{*}{ Debt_S } & RDSt & LnPatent $(t+1)$ & RDSt & LnPatent $(t+1)$ \\
\hline & $-0.538^{* * *}$ & $-0.085^{*}$ & & \\
\hline & $(-2.97)$ & $(-1.96)$ & & \\
\hline \multirow[t]{2}{*}{ Debt_S $\times$ Trading } & 0.196 & 0.504 & & \\
\hline & (1.33) & $(0.51)$ & & \\
\hline \multirow[t]{2}{*}{ Debt_L } & & & -0.298 & -0.053 \\
\hline & & & $(-1.64)$ & $(-1.23)$ \\
\hline \multirow[t]{2}{*}{ Debt_L $\times$ Trading } & & & 0.116 * & $0.858^{* * *}$ \\
\hline & & & $(1.68)$ & $(2.64)$ \\
\hline \multirow[t]{2}{*}{ Trading } & $0.054^{* *}$ & $-0.415^{* * *}$ & $0.044^{*}$ & $-0.493^{* * *}$ \\
\hline & $(2.08)$ & $(-6.65)$ & $(1.84)$ & $(-7.12)$ \\
\hline \multirow[t]{2}{*}{ LNTA } & $0.107^{* * *}$ & $0.110^{* * *}$ & $0.106^{* * *}$ & $0.112^{* * *}$ \\
\hline & $(2.75)$ & $(7.65)$ & $(2.59)$ & $(7.77)$ \\
\hline \multirow{2}{*}{ Tangibility } & -0.365 & $0.242 * * *$ & -0.368 & $0.242^{* * *}$ \\
\hline & $(-1.50)$ & $(3.18)$ & $(-1.41)$ & $(3.17)$ \\
\hline \multirow[t]{2}{*}{ Profitability } & $-1.119 * * *$ & -0.030 & $-1.077^{* * *}$ & -0.027 \\
\hline & $(-6.24)$ & $(-1.40)$ & $(-5.98)$ & $(-1.32)$ \\
\hline \multirow[t]{2}{*}{ МTB } & 0.027 * & $0.013^{* * *}$ & $0.028 *$ & $0.013^{* * *}$ \\
\hline & $(1.93)$ & $(4.66)$ & $(1.66)$ & $(4.64)$ \\
\hline \multirow[t]{2}{*}{$\mathrm{HHI}$} & 0.421 & $0.981^{* * *}$ & 0.372 & $0.984^{* * *}$ \\
\hline & (1.11) & $(2.96)$ & $(0.97)$ & $(2.96)$ \\
\hline \multirow[t]{2}{*}{ HHI2 } & -0.277 & $-0.845^{* *}$ & -0.233 & $-0.847^{* *}$ \\
\hline & $(-0.92)$ & $(-2.49)$ & $(-0.77)$ & $(-2.49)$ \\
\hline \multirow[t]{2}{*}{ Signaling } & $0.007^{* * *}$ & 0.001 & $0.008^{* * *}$ & 0.001 \\
\hline & $(3.28)$ & $(1.01)$ & $(3.36)$ & $(0.96)$ \\
\hline \multirow[t]{2}{*}{ Asset Maturity } & 0.003 & $-0.002^{* * *}$ & 0.004 & $-0.002^{* * *}$ \\
\hline & $(1.40)$ & $(-4.18)$ & $(1.25)$ & $(-4.17)$ \\
\hline \multirow[t]{2}{*}{ Taxes } & 0.001 & 0.007 & 0.003 & 0.007 \\
\hline & $(0.17)$ & $(0.86)$ & $(0.43)$ & $(0.85)$ \\
\hline \multirow[t]{2}{*}{ Constant } & -0.364 & $-0.911^{* * *}$ & -0.335 & $-0.920 * * *$ \\
\hline & $(-1.26)$ & $(-7.99)$ & $(-1.13)$ & $(-8.06)$ \\
\hline Firm FE & YES & YES & YES & YES \\
\hline Year FE & YES & YES & YES & YES \\
\hline $\mathrm{N}$ & 34,201 & 34,201 & 34,201 & 34,201 \\
\hline Adj-R2 & 0.702 & 0.774 & 0.700 & 0.774 \\
\hline
\end{tabular}

Note: This table presents the regression results of CDS trading on the relation between debt and innovation conditional on debt term. Variable definitions are shown in Table 1. In columns (1) and (2), the explanatory variable is the interaction term of short-term debt and CDS trading. In columns (3) and (4), the explanatory variable is the interaction term of long-term debt and CDS trading. T-statistics in parentheses are calculated based on standard error clustered by firm and robust to heteroscedasticity; $* * *$, and ${ }^{* * *}$ denote significance at $10 \%, 5 \%$, and $1 \%$ level using two-tailed $t$-tests, respectively.

\subsection{Endogeneity Tests}

One major concern for our baseline results is that CDS initiation may be endogenous. Some uncontrolled factors may affect the CDS initiation and the association between debt and 
innovation simultaneously. In this section, we employ two econometrical approaches to address this endogeneity concern. In Section 4.4.1, we use a propensity score matching (PSM) approach to identify more comparable non-CDS firms to CDS-firms and re-estimate Equation (1). In Section 4.4.2, we adopt an instrumental variable (IV) approach to control for unobservable factors affecting our estimation results.

\subsubsection{Propensity Score Matching}

We employ a propensity score matching (PSM) method to identify a control group. The control group identified by this method has similar characteristics relevant for CDS initiation to CDS firms. Therefore, the resulting matched non-CDS firms are more comparable with CDS firms. Following Ashcraft and Santos [47] and Martin and Roychowdhury [41], we first predict the initiation of CDS trading using the following logistic model:

$$
\begin{aligned}
\operatorname{Prob}\left(\mathrm{CDS}_{\mathrm{t}}=1\right)= & \varphi\left(\beta_{0}+\beta_{1} \text { Grade }_{\mathrm{t}-1}+\beta_{2} \text { Rating }_{\mathrm{t}-1}+\beta_{3} \text { Debt }_{\mathrm{t}-1}+\beta_{4} \text { Margin }_{\mathrm{t}-1}\right. \\
& \left.+\beta_{5} \mathrm{LME}_{\mathrm{t}-1}+\beta_{6} \text { Retvol }_{\mathrm{t}-1}+\beta_{7} \mathrm{MTB}_{\mathrm{t}-1}\right)+\varepsilon_{\mathrm{i}, \mathrm{t}}
\end{aligned}
$$

where $C D S$ is a dummy variable that equals one if a firm is referenced by a CDS contract during our sample period (from 2001 to 2010), and zero otherwise. Grade is an indicator variable that equals one if a firm has an S\&P (Standard \& Poor's) credit rating above BB+, and zero otherwise. Rating is an indicator variable that equals one if a firm has an S\&P credit rating, and zero otherwise. Debt is defined as a firm's total debt scaled by total assets. Margin is profit margin, calculated as net income divided by sales. $L M E$ measures firm size, defined as the natural logarithm of a firm's market capitalization. RETVOL is stock return volatility, measured as the standard deviation of the monthly stock returns. MTB is market-to-book ratio, equal to market capitalization divided by the book value of equity. Following Martin and Roychowdhury [41], the logistic regression sample includes all firm-years for non-CDS firms and only firm-years before the initiation for CDS firms. To ensure observations prior to the CDS initiation included, we extend the sample period to 1996-2010 for estimating the propensity score of CDS initiation [40]. Then, we regress the Equation (2) using this extended sample.

Next, we match each CDS firm with three non-CDS firms that are in the same industry (Fama-French 48 industry classifications) as the CDS firms and have the closest propensity scores of CDS initiation prior to the onset of CDS trading. Consistent with Martin and Roychowdhury [40], we ensure that each of the non-CDS firms enters into the sample once each year. After these procedures, we re-estimate Equation (1) using this matched sample. The results are shown in Table 4 . In columns (1) and (2), the coefficients on the interaction term (Debt $\times$ Trading) are all positive and significant (t-statistics $=4.96$ for R\&D and 2.04 for patent, respectively). The PSM regression results substantiate our Hypothesis 2. 
Table 4. Propensity Score Matching (PSM).

\begin{tabular}{ccc}
\hline Variables & $\mathbf{( 1 )}$ & $\mathbf{( 2 )}$ \\
\hline & RDSt & LnPatent $(t+1)$ \\
Debt & 0.030 & $-0.593^{* * *}$ \\
Debt $\times$ Trading & $(1.35)$ & $(-2.85)$ \\
& $0.119^{* * *}$ & $0.702^{* *}$ \\
Trading & $(4.96)$ & $(2.04)$ \\
& -0.003 & 0.139 \\
Control variables & $(-0.27)$ & $(1.51)$ \\
Firm FE & YES & YES \\
Year FE & YES & YES \\
$N$ & YES & YES \\
Adj-R2 & 8470 & 8470 \\
\hline
\end{tabular}

Note: This table reports the re-estimated regression results of Equation (1) based on a matched sample. Variable definitions are shown in Table 1. In column (1), the dependent variable is R\&D intensity. In column (2), the dependent variable is patent count. T-statistics in parentheses are calculated based on standard error clustered by firm and robust to heteroscedasticity; ${ }^{*}, * *$, and ${ }^{* * *}$ denote significance at $10 \%, 5 \%$, and $1 \%$ level using two-tailed $t$-tests, respectively. Given the limited space, we omitted the regression results of the control variables.

\subsubsection{Two-Stage Instrumental Variable Estimation}

In previous section, we employ PSM matching to control for some observable firm-level characteristics that may affect CDS initiation and the relation between debt and innovation simultaneously. However, there may exist some unobservable factors driving the estimation results. In this section, we use the instrumental variable approach to address this potential problem. Following Saretto and Tookes [40] and Subrahmanyam et al. [48], we use the foreign exchange derivative position of the firm's lenders and underwriters ( $F X_{-}$Deriv) as an instrumental variable for CDS trading. To calculate FX_Deriv, we first use Dealscan and FISD (Fixed Income Securities Database) data to identify CDS firms' lenders and bond underwriters. Then, we obtain the data on the foreign exchange derivatives positions of these lenders and bond underwriters from the Fed Call Report. Finally, FX_Deriv is calculated as the average amount of foreign exchange derivative positions relative to total assets over the past five years across the lenders and bond underwriters.

To further alleviate the concern that the inception of CDS trading might be an endogenous variable related to omitted correlated variables, we adopt the two-stage least squares approach. In the first stage, we estimate the fitted value of CDS trading as instrumented trading (I_Trading) using the following model:

$$
\begin{aligned}
\text { Trading }_{\mathrm{i}, \mathrm{t}}= & \beta_{0}+\beta_{1} \text { FX_Deriv }_{\mathrm{i}, \mathrm{t}}+\beta_{2} \text { Debt }_{\mathrm{i}, \mathrm{t}}+\beta_{3} \text { Controls }_{\mathrm{i}, \mathrm{t}}+\text { Year Effect }_{\mathrm{t}} \\
& + \text { Firm Effect }_{\mathrm{i}}+\text { error }_{\mathrm{i}, \mathrm{t}}
\end{aligned} .
$$

In the second stage, we replace the CDS trading variable (Trading) with our instrumented trading (I_Trading) and re-estimate using Equation (1). Table 5 shows the empirical results of the two-stage regressions. In the first stage (column 1), with all the other CDS initiation relevant variables controlled, FX_Deriv is significantly positive to CDS trading ( $\mathrm{t}$-statistics $=3.38$ ). This demonstrates that FX_Deriv meets the relevance requirement for instrument variable approach. In the second stage, the coefficients on the interaction term of instrumented CDS trading and debt are significantly positive in both models (t-statistics $=2.02$ for R\&D and t-statistics $=3.66$ for patent, respectively). The evidence in Table 5 suggests that the impact of CDS trading on the relation between debt and innovation remains robust after controlling for potential endogeneity issues, lending additional support to our Hypothesis 2. 
Table 5. Two-stage Instrumental Variable Regression (IV).

\begin{tabular}{cccc}
\hline Variables & First Stage & Second Stage & Second Stage \\
\hline \multirow{2}{*}{ FX_Deriv } & Tradingt & RDSt & LnPatent $(t+1)$ \\
& $0.011^{* * *}$ & & \\
Debt & $(3.38)$ & $-0.394^{* * *}$ & $-0.139^{* * *}$ \\
& -0.005 & $(-4.45)$ & $(-3.67)$ \\
Debt $\times$ I_Trading & $(-0.82)$ & $7.399^{* *}$ & $2.793^{* * *}$ \\
& & $(2.02)$ & $(3.66)$ \\
I_Trading & & $-8.494^{* * *}$ & $2.054^{* * *}$ \\
Control variables & & $(-4.96)$ & $(5.46)$ \\
Firm FE & YES & YES & YES \\
Year FE & YES & YES & YES \\
N & YES & YES & YES \\
Adj-R2 & 39,472 & 39,472 & 39,472 \\
\end{tabular}

Note: This table presents the regression results of CDS trading on the relation between debt and innovation using IV approach. FX_Deriv is the instrument variable. In the first stage, we instrument Trading with FX_Deriv and compute the fitted value of Trading as instrumented trading variable (I_Trading). In the second stage, we replace the original Trading with the instrumented trading variable (I_Trading) variable in the original baseline regressions. Trading is A dummy variable, equals 1 if a firm has active CDS trading by year $t$, and 0 otherwise. RDS is defined as research and development expenses scaled by total sales in year $\mathrm{t}$. LnPatent is measured as the natural logarithm of one plus patent count of firm in year t. Variable definitions are shown in Table 1. T-statistics in parentheses are calculated based on standard error clustered by firm and robust to heteroscedasticity; * **, and *** denote significance at $10 \%, 5 \%$, and $1 \%$ level using two-tailed $t$-tests, respectively. Given the limited space, we omitted the regression results of the control variables.

\section{Channels for the Reduced Negative Effect of Debt on Innovation}

We are interested to know the potential channels for such a decrease. We examine the conditional impact of CDS trading from both CEOs' incentive side and financial channels side. We find that the mitigation effect of CDS on the relation between debt and innovation is more pronounced for CDS firms with higher pay sensitivity to stock price volatility (Vega) and less financial constraints.

\subsection{CEO Incentive Channel}

As we elaborated above, the fact that debtholders reducing their monitoring after CDS trading does not necessarily result in CEOs' decisions to invest more in R\&D, unless CEOs are incentivized to do so. Hence, considering CEO compensation structure, the effect of CDS trading on the relation between debt and innovation should be more pronounced for firms whose CEOs' compensation are more sensitive to stock price volatility (Vega). We construct two measures for CEO compensation (Vega). Following Core and Guay [57], we construct VegaC, measured as the change in the value of the CEO's annual equity based compensation for a 0.01 change in stock price volatility. In addition, following Hayes, Lemmon, and Qiu [58], we construct VegaT, computed as the change in the value of CEO's total portfolio of current and outstanding prior grants of shares and options for a 0.01 change in stock price volatility. Next, we divide our sample into sub-samples according to the median values of VegaC and $V e g a T$. Specifically, we define a firm in VegaC_High group when the VegaC of firm $i$ is above the median value of VegaC in year $t$, and define a firm in VegaC_Low group when the VegaC of firm $i$ is below or equal to the median value of VegaC in year t.VegaT_High and VegaT_Low are defined in a similar way.

Table 6 presents the regression results regarding the differential effect of the CDS trading on the relation between debt and innovation in high and low Vega sub-samples, respectively. From columns (1) to (8), we find that for both measures of CEO risk taking (VegaC and VegaT), the effect of CDS trading on the relation between debt and innovation is more pronounced for firms with higher Vega, as the coefficients of CDS trading and debt are all positive and significant in Vega_High groups (t-statistics $=2.69,2.87,2.28$, and 2.23 in columns (1), (3), (5), and (7), respectively), but insignificant in Vega_Low groups (t-statistics $=-1.08,-0.54,0.25$, and 0.43 in columns (2), (4), (6), and (8), respectively). 
In addition, we perform a series of significance tests using seemingly unrelated estimation to test whether the coefficients across Vega_High group and Vega_Low group are significantly different from each other, and the results are shown in the last two rows. All of the four intergroup coefficients difference tests are statistically significant $\left(\mathrm{Chi}^{2}=7.94,5.11,6.60\right.$, and 2.96 , respectively). In summary, the regression results suggest that the effect of CDS trading on the relation between debt and innovation is more pronounced when the CEO's compensation is more sensitive to stock price volatility. Our interpretation is that with the onset of CDS, firms whose CEO's compensation is more aligned with firm future performance are incentivized to investment more in innovation.

Table 6. CEO Compensation Channel.

\begin{tabular}{|c|c|c|c|c|c|c|c|c|}
\hline \multirow{2}{*}{ Variables } & \multicolumn{2}{|c|}{ RDSt } & \multicolumn{2}{|c|}{ RDSt } & \multicolumn{2}{|c|}{ LnPatent $(t+1)$} & \multicolumn{2}{|c|}{ LnPatent $(t+1)$} \\
\hline & (1) & (2) & (3) & (4) & (5) & (6) & (7) & (8) \\
\hline Debt & $\begin{array}{c}\text { VegaT_High } \\
-0.376^{* * *} \\
(-2.59)\end{array}$ & $\begin{array}{c}\text { VegaT_Low } \\
-0.310 \\
(-0.62)\end{array}$ & $\begin{array}{c}\text { VegaC_High } \\
-0.383 * * * * \\
(-2.81)\end{array}$ & $\begin{array}{c}\text { VegaC_Low }=0 \\
-0.312 \\
(-0.47)\end{array}$ & $\begin{array}{c}\text { VegaT_High } \\
-0.114 * * * \\
(-3.09)\end{array}$ & $\begin{array}{c}\text { VegaT_Low } \\
-0.141 \\
(-1.34)\end{array}$ & $\begin{array}{c}\text { VegaC_High } \\
-0.100 * * * \\
(-2.87)\end{array}$ & $\begin{array}{c}\text { VegaC_Low } \\
-0.210 \\
(-1.52)\end{array}$ \\
\hline $\begin{array}{c}\text { Debt } \times \\
\text { Trading }\end{array}$ & $0.192 * * *$ & -0.425 & $0.205^{* * *}$ & -0.203 & $0.843^{* *}$ & 0.170 & $0.797^{* *}$ & 0.365 \\
\hline Trading & $\begin{array}{l}(2.69) \\
0.037 \\
(1.26)\end{array}$ & $\begin{array}{l}(-1.08) \\
-0.040 \\
(-0.73)\end{array}$ & $\begin{array}{l}(2.87) \\
0.031 \\
(1.11)\end{array}$ & $\begin{array}{l}(-0.54) \\
0.035 \\
(0.68)\end{array}$ & $\begin{array}{c}(2.28) \\
-0.507 * * * \\
(-6.41)\end{array}$ & $\begin{array}{c}(0.25) \\
-0.299 * * \\
(-2.16)\end{array}$ & $\begin{array}{c}(2.23) \\
-0.509 * * * \\
(-6.43)\end{array}$ & $\begin{array}{l}(0.43) \\
-0.054 \\
(-0.50)\end{array}$ \\
\hline $\begin{array}{c}\text { Control } \\
\text { variables }\end{array}$ & YES & YES & YES & YES & YES & YES & YES & YES \\
\hline Firm FE & YES & YES & YES & YES & YES & YES & YES & YES \\
\hline Year FE & YES & YES & YES & YES & YES & YES & YES & YES \\
\hline $\mathrm{N}$ & 4941 & 4943 & 5093 & 4791 & 4941 & 4943 & 5093 & 4791 \\
\hline Adj-R2 & 0.665 & 0.444 & 0.666 & 0.432 & 0.770 & 0.771 & 0.757 & 0.842 \\
\hline \multicolumn{9}{|c|}{ Test of the difference of $B 3$} \\
\hline $\mathrm{H} 0$ & \multicolumn{2}{|c|}{$(1)-(2)=0$} & \multicolumn{2}{|c|}{ (3) $-(4)=0$} & \multicolumn{2}{|c|}{$(5)-(6)=0$} & \multicolumn{2}{|c|}{$(7)-(8)=0$} \\
\hline $\mathrm{Chi}^{2}$ & \multicolumn{2}{|c|}{$7.94 * * *$} & \multicolumn{2}{|c|}{$5.11^{* *}$} & \multicolumn{2}{|c|}{$6.60^{* *}$} & \multicolumn{2}{|c|}{$2.96 *$} \\
\hline
\end{tabular}

Note: This table presents the regression results of CDS trading on the relation between debt and innovation conditional on CEO compensation structure. We split our sample into Vega_Low and Vega_High groups according to the median values of VegaT and VegaC, respectively. We perform significance tests and present the results in the last two rows. T-statistics in parentheses are calculated based on standard error clustered by firm and robust to heteroscedasticity; ${ }^{* * *}$, and ${ }^{* * *}$ denote significance at $10 \%, 5 \%$, and $1 \%$ level using two-tailed $t$-tests, respectively. Given the limited space, we omitted the regression results of the control variables.

\subsection{Financial Constraints Channel}

Due to the concern of debt repayment, financially constrained firms are less likely to use debt as the financing of innovation without CDS being traded. As a consequence, the effect of CDS trading on the relation between debt and innovation should be more pronounced for more financially constrained firms due to the reduced creditors' monitoring. Following prior literature $[59,60]$, we use KZ index and S\&P credit rating to measure the level of a firm's financial constraints. Consistent with the literature, we define $K Z_{-}$High as the $\mathrm{KZ}$ index of firm $i$ in year $t$ that is above the median value in year $t$, and $K Z \_L o w$ as the $\mathrm{KZ}$ index of firm $i$ in year $t$ that is below or equal to the median value in year $t$. We define Rated as the firm $i$ in year $t$ that has a S\&P credit rating, and Unrated otherwise. According to the variables defined above, we divide our sample into four sub-samples. The KZ_High and Unrated group firms are more financially constrained, while $K Z \_L o w$ and Rated group firms are less financially constrained.

Table 7 presents the regression results based on the sub-samples we divide. The results show that in less financially constrained sub-samples (columns (1), (3), (5), and (7)), the coefficients on the interaction terms are positive and significant (t-statistics $=2.27,2.15,2.47$, and 3.00, respectively), while in more financially constrained sub-samples (columns (2), (4), (6), and (8)), the coefficients are insignificant (t-statistics $=-0.11,-1.29,0.26$, and -1.04 , respectively). Opposite to our expectation, we find that the effect of CDS trading on the relation between debt and innovation is more pronounced for less financially constrained firms. The results suggest that after the onset of CDS trading, firms with less financial constraints are more likely to use debt as financing of innovation. In addition, the last two rows in Table 6 reflect that the difference in the coefficients among sub-samples are all significant 
$\left(\mathrm{Chi}^{2}=3.99,6.93,3.78\right.$, and 4.96, respectively). Overall, the findings in Table 7 are opposite to what we hypothesize, revealing that the increase in financing channels due to the relaxed financing constraints caused by the onset of CDS might not be the underlying channel for the condensed negative impact of debt on innovation after CDS trading.

Table 7. Financial Constraints Channel.

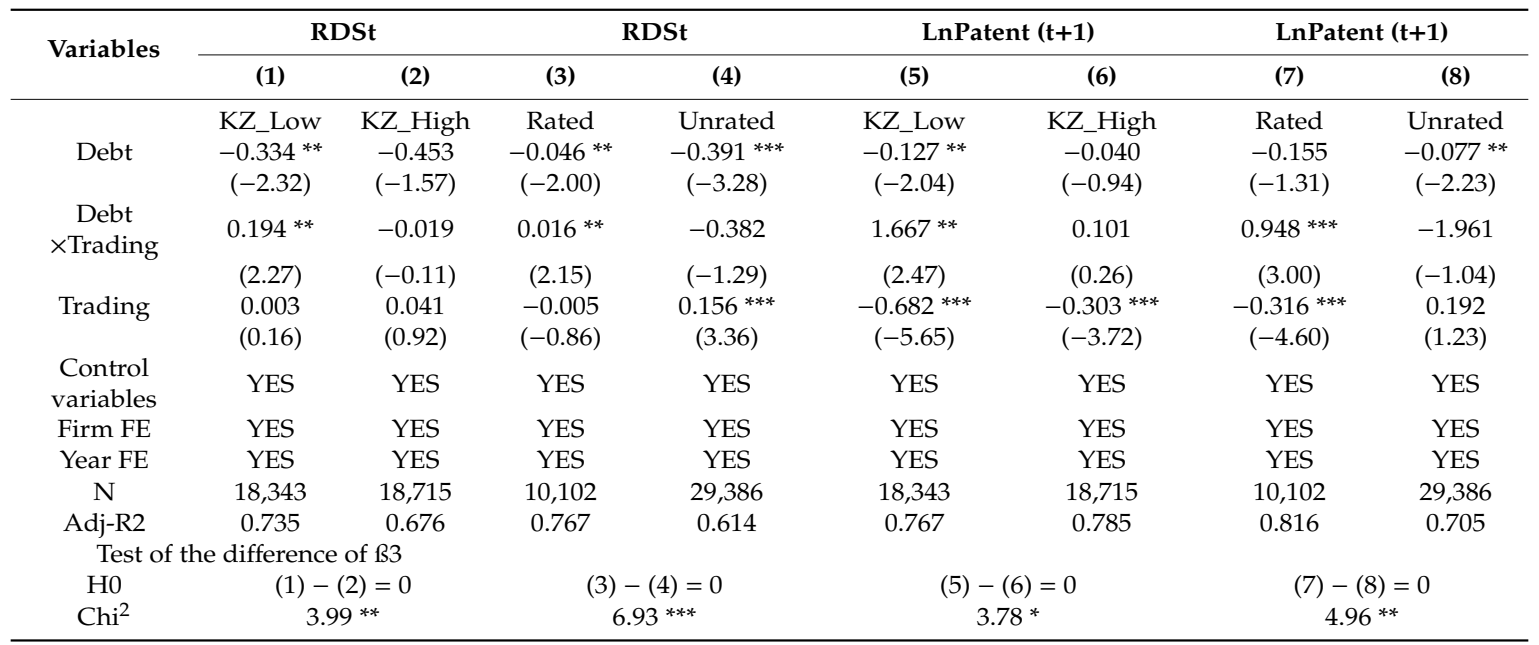

Note: This table presents the regression results of CDS trading on the relation between debt and innovation conditional on a firm's financial constraints. We split our sample into KZ_Low and KZ_High groups according to the median values of KZ index. We define Rated and Unrated groups based on S\&P credit rating. We perform significance tests and present the results in the last two rows. T-statistics in parentheses are calculated based on standard error clustered by firm and robust to heteroscedasticity: ***, and *** denote significance at $10 \%, 5 \%$, and $1 \%$ level using two-tailed $t$-tests, respectively. Given the limited space, we omitted the regression results of the control variables.

\section{Robustness Analysis}

In this section, we first use current debt measures instead of cumulative measures to test the robustness of our main analysis. Second, to rule out the possibility that the truncations bias of patent count data affect our regression results, we follow the literature and use a weighting adjusted patent count to test the robustness of our main results. Third, given the effect of business cycle on corporate debt financing, we control for the business cycle and re-examine our hypotheses. Lastly, we test the difference in the effect of CDS trading in financial crisis period and non-crisis period.

\subsection{Different Debt Measures: Using Current Debt}

One might question that cumulative debt level cannot precisely reflect the effect of CDS trading on the debt usage. In this section, we construct two current debt level measures to address this potential problem. The first one is current short-term debt (Debt_CS), measured as the short-term debt in year $t$ minus the short-term debt in year $t-1$. The second one is current long-term debt (Debt_CL), measured as the long-term debt in year $t$ minus the long-term debt in year $t-1$. Then, we construct the interactions terms of current debt and CDS trading for these two debt measures and replace the interaction term in Equation (1), respectively.

Table 8 shows the regression results using these current debt measures. In columns (1) and (2), the coefficients on the interaction term of current short-term debt and CDS trading (Debt_CS $\times$ Trading) are both insignificant (t-statistics $=1.63$ and -0.75 ). In columns (3) and (4), the coefficients on the interaction term of current long-term debt and CDS trading (Debt_CL $\times$ Trading) are both positively significant (t-statistics $=2.22$ and 2.90), indicating that the negative impact of long-term debt on innovation is reduced after the onset of CDS trading, but not for the relation between short-term debt and innovation. In other words, the effect of CDS trading on the relation between debt and innovation 
is more pronounced for long-term debt than for short-term debt. Thus, our Hypothesis 3 still holds when using the current measures of debt.

Table 8. Current Short-Term vs. Long-Term Debt.

\begin{tabular}{ccccc}
\hline & $\mathbf{( 3 )}$ & $\mathbf{( 4 )}$ & $\mathbf{( 5 )}$ & $\mathbf{( 6 )}$ \\
\hline & RDSt & LnPatent $(t+$ & RDSt & LnPatent $(t+$ \\
Debt_CS & $-0.212^{* *}$ & $-0.038^{*}$ & & $1)$ \\
& $(-2.05)$ & $(-1.76)$ & & \\
Debt_CS $\times$ & 0.197 & -0.424 & & \\
Trading & $(1.63)$ & $(-0.75)$ & & \\
& & & -0.133 & -0.007 \\
Debt_CL & & & $(-1.59)$ & $(-0.27)$ \\
& & & $0.208 * *$ & $1.950 * * *$ \\
Debt_CL $\times$ & & & $(2.22)$ & $(2.90)$ \\
Trading & & & 0.020 & $-0.447^{* * *}$ \\
& & & $(0.85)$ & $(-6.38)$ \\
Trading & 0.015 & $-0.455 * * *$ & YES & YES \\
Control & $(0.61)$ & $(-6.41)$ & Yes & Yes \\
variables & YES & YES & Yes & Yes \\
Firm FE & Yes & Yes & 39,488 & 39,488 \\
YearFE & Yes & Yes & 0.647 & 0.764 \\
N & 39,488 & 39,488 & 0.763 & \\
Adj-R2 & 0.655 &
\end{tabular}

Note: This table presents the regression results of CDS trading on the relation between debt and innovation conditional on debt term after using the current measures of debt. Variable definitions are shown in Table 1. T-statistics in parentheses are calculated based on standard error clustered by firm and robust to heteroscedasticity; $* * *$, and ${ }^{* * *}$ denote significance at $10 \%, 5 \%$, and $1 \%$ level using two-tailed $t$-tests, respectively. Given the limited space, we omitted the regression results of the control variables.

\subsection{Truncation Bias of Patent Data}

Since our patent data ends in 2010, patents applied in the last few years may be under review and not granted by the end of 2010. To correct this potential truncation bias, we follow Atanassov [11] and construct a weighting adjusted measure, calculated as the number of patents for each firm-year divided by the mean number of patents for the same year. Next, we use the natural logarithm of one plus this adjusted patent count measure (LnPatent ${ }_{a d j}$ ) to stand for innovation output and test our hypothesis using Equation 1.

Table 9 presents the regression results after using the weighting adjusted measure of patent count in the subsequent one, two, and three years, respectively. In columns (1), (2), and (3), the coefficients on the interaction term of debt and CDS trading are both positive and significant ( $\mathrm{t}$-statistics $=6.12,4.64$, and 4.61, respectively), indicating that after adjusting the potential truncation bias of patent count, the effect of CDS trading on the relation between debt and innovation still holds. Thus, our regression results are less likely to be driven by patent truncation bias. 
Table 9. Patent Truncation Bias.

\begin{tabular}{cccc}
\hline & $\mathbf{( 1 )}$ & $\mathbf{( 2 )}$ & $\mathbf{( 3 )}$ \\
\hline \multirow{2}{*}{ Debt } & LnPatent $(t+1)$ & LnPatent $(t+2)$ & LnPatent $(t+3)$ \\
& $-0.028^{* * *}$ & $-0.038^{* * *}$ & $-0.030^{* * *}$ \\
Debt $\times$ Trading & $(-2.76)$ & $(-3.60)$ & $(-2.58)$ \\
& $0.377^{* * *}$ & $0.344^{* * *}$ & $0.421^{* * *}$ \\
Trading & $(6.12)$ & $(4.64)$ & $(4.61)$ \\
& $-0.275^{* * *}$ & $-0.298^{* * *}$ & $-0.311^{* * *}$ \\
Control variables & $(-22.99)$ & $(-22.74)$ & $(-21.97)$ \\
Firm FE & YES & YES & YES \\
Year FE & YES & YES & YES \\
$\mathrm{N}$ & YES & YES & YES \\
Adj-R2 & 39,488 & 37,219 & 35,018 \\
\hline
\end{tabular}

Note: This table presents the regression results of CDS trading on the relation between debt and innovation after correcting the potential truncation bias of patent data. Variable definitions are shown in Table 1. T-statistics in parentheses are calculated based on standard error clustered by firm and robust to heteroscedasticity; ${ }^{*}, * *$, and ${ }^{* * *}$ denote significance at $10 \%, 5 \%$, and $1 \%$ level using two-tailed $t$-tests, respectively. Given the limited space, we omitted the regression results of the control variables.

\subsection{Control for Business Cycle}

Because both of debt and the opportunity cost of debt financing is cyclical, business cycle may affect the difficulty of getting access to debt financing for firms. To enhance the robustness of our main results, we control for effect of business cycle in our model and re-examine our hypotheses. Following Bangia et al. [61], we divide the business cycle into two states, expansion and recession, using the NBER business cycle classifications. According to NBER classification (Data source: https://www.nber.org/cycles/cyclesmain.html), the period between 2008 and 2009 is a recession period, and the rest of our sample period is an expansion period. We construct a dummy variable, Cycle, which equals one for the recession period, and zero otherwise. We include this variable into model (1) and re-examine the hypotheses. Table 10 presents the results, where we find that after controlling for business cycle, our hypotheses are supported. The negative coefficients on Cycle suggest that compared with expansion periods, firms reduce their innovation activities during the recession periods.

Table 10. Control for Business Cycle.

\begin{tabular}{ccc}
\hline Variables & $\mathbf{( 1 )}$ & $\mathbf{( 2 )}$ \\
\cline { 2 - 3 } & $\mathbf{R D S t}$ & LnPatent $(\boldsymbol{t + 1 )}$ \\
\hline Debt & $-0.426^{* * *}$ & $-0.086^{* * *}$ \\
& $(-3.01)$ & $(-2.62)$ \\
Debt $\times$ Trading & $0.180^{* *}$ & $0.851^{* * *}$ \\
& $(2.39)$ & $(2.70)$ \\
Trading & $0.043^{*}$ & $-0.460^{* * *}$ \\
& $(1.72)$ & $(-6.72)$ \\
Cycle & $-0.148^{* * *}$ & $-0.593^{* * *}$ \\
& $(-2.58)$ & $(-25.54)$ \\
Control variables & YES & YES \\
Firm FE & YES & YES \\
Year FE & YES & YES \\
N & 39,488 & 39,488 \\
Adj-R2 & 0.673 & 0.759
\end{tabular}

Note: This table presents the regression results of CDS trading on the relation between debt and innovation after controlling for the effect of business cycle. Variable definitions are shown in Table 1. T-statistics in parentheses are calculated based on standard error clustered by firm and robust to heteroscedasticity; *,**, and *** denote significance at $10 \%, 5 \%$, and $1 \%$ level using two-tailed $t$-tests, respectively. Given the limited space, we omitted the regression results of the control variables. 


\subsection{The Effect of Financial Crisis}

The global financial crisis of 2007 to 2009 may significantly bias our results, since firms in tough periods may reduce risky investment activities. Financial crisis maybe a significant factor driving the effect of CDS trading on debt financing of innovation. Consequently, we re-examine our main hypotheses in the subsamples of financial crisis period and non-crisis period. We divide the sample between the period of 2007 and 2008 as crisis period, and the rest as non-crisis period. The results are shown in Table 11. Consistent with our conjecture, the effect of CDS trading on the relation between debt and innovation is significant in the non-crisis period, while insignificant in the crisis period. The results imply that financial crisis may restrain the positive effects of CDS trading on the debt financing of innovation.

Table 11. The Effect of Financial Crisis.

\begin{tabular}{ccccc}
\hline \multirow{2}{*}{ Variables } & $\mathbf{( 1 )}$ & $\mathbf{( 2 )}$ & $\mathbf{( 3 )}$ & $\mathbf{( 4 )}$ \\
\cline { 2 - 5 } & Crisis & Crisis & Non-Crisis & Non-Crisis \\
\hline \multirow{2}{*}{ Debt } & RDSt & LnPatent $(t+1)$ & RDSt & LnPatent $(t+1)$ \\
& -0.126 & 0.046 & $-0.422^{* * *}$ & $-0.073^{* *}$ \\
Debt $\times$ Trading & $(-0.30)$ & $(0.57)$ & $(-2.99)$ & $(-2.08)$ \\
& -0.000 & -0.154 & $0.212 * * *$ & $1.103^{* * *}$ \\
Trading & $(-0.00)$ & $(-0.30)$ & $(2.88)$ & $(2.65)$ \\
& 0.024 & -0.234 & 0.040 & $-0.498^{* * *}$ \\
Control variables & $(1.05)$ & $(-1.61)$ & $(1.49)$ & $(-6.54)$ \\
Firm FE & YES & YES & YES & YES \\
Year FE & YES & YES & YES & YES \\
N & YES & YES & YES & YES \\
Adj-R2 & 10,792 & 28,696 & 10,792 & 28,696 \\
\hline
\end{tabular}

Note: This table presents the subsample regression results of CDS trading on the relation between debt and innovation in different period of financial crisis. Variable definitions are shown in Table 1. T-statistics in parentheses are calculated based on standard error clustered by firm and robust to heteroscedasticity; ${ }^{*}, * *$, and ${ }^{* * *}$ denote significance at $10 \%, 5 \%$, and $1 \%$ level using two-tailed $t$-tests, respectively. Given the limited space, we omitted the regression results of the control variables.

\section{Discussion}

Extensive research has suggested that debt tends to be a disfavored source of financing for innovation $[5,7,33]$. Recent evidence, however, has shown that debt financing may play an important role in the financing of innovation [62] (with respect to entrepreneurship, Robb and Robinson [63] have found that many entrepreneurs have financed their new ventures by debts; however, these debts are personal debts rather than company debts. Similar to CDSs, personal debts may function as insurance for creditors. By granting personal debts rather than company debts, creditors may not be affected by the bankruptcy risks of new ventures. However, personal debts tend to be much smaller in scale than company debts; consequently, personal debts can be used to finance small business, but they will not be able to support entrepreneurship and innovation in large corporations.) Nevertheless, none of the existing studies investigate how a financial instrument facilitates debt financing in sustainable innovation investments (in a related work, Chang et al. [64] investigated the relation between CDS trading and innovation and found a positive effect of CDS trading on innovation output. Our paper differs from theirs on the following aspects. First, our paper focuses on the debt financing of innovation and investigates how CDS trading changes the relation between debt and innovation. Debt is our explanatory variable, while in Chang et al. [64], their variable of interest was CDS trading. Second, we identify a new economic channel, CEO compensation incentive, through which CDS trading facilitates the debt financing of innovation. In Chang et al. [64] they showed that the increase in the innovation output after the onset of CDS trading is due to the tolerance for failure. Overall, the focus of our work is different from Chang et al. [64], and we provide further 
insights about this topic by implying a new underlying channel, CEO compensation incentive). In this paper, we propose that CDSs may facilitate the use of debt, especially long-term debt, in the financing of innovation.

Drawing on a sample of R\&D performing firms during the period between 2001 and 2010, we document that after the onset of CDS trading, the magnitude of the negative association between a firm's debt level and its R\&D intensity significantly decreases. Furthermore, we find that the availability of CDSs is more likely to change the nature of long-term debt than that of short-term debt, making long-term debt a useful instrument for the financing of innovation. Our interpretation is that CDSs change the institutional logics of debt and the relation between debtors and creditors. Without CDS protection, creditors have to bear the risks of debtor defaults. With CDS protection, creditors are not affected by debtors' change in risk profile and reduce their monitoring on the debtors. By reallocating risk bearing, CDSs may have turned debt from an unforgiving instrument into an instrument that is more likely to tolerate risk taking, experimentation, and early failure. Importantly, with the right incentive design, CEOs spend more on $R \& D$ and achieve high innovation outputs (patents), helping firms to maintain sustainability.

Opposite to our expectation that firms that are more financially constrained should benefit more from the onset of CDS trading, we find that such an impact is actually more pronounced for less financially constrained firms. This finding suggests that having more access to capital with the introduction of CDS might not be the channel for our findings. In other words, we must realize that even though CDSs allow creditors to hedge credit risk, making them more willing to lend money to firms to finance R\&D activities with substantial risk, this might not be the root cause of our findings. In fact, CDS-insured creditors become more likely to push borrowers into inefficient bankruptcy to obtain default payment from CDS sellers during liquidation [14,48]. In response to this empty creditor problem caused by CDSs, managers tend to hold more cash [49]. Consequently, firms in financial distress may now become more vulnerable when CDSs are traded on their debt and less willing to invest in risky innovation projects. It is more likely that the more alignment between CEO's incentive and firm future performance is the channel for the improved compatibility between debt and R\&D after CDS trading.

Since the global financial crisis of 2007-2009, CDSs have been harshly criticized and regarded as the fuse of the crisis. The findings in this paper so far advance our knowledge on the positive impact of CDS from the firms' innovation, which is vital for the sustainable development of organization and economy. CDSs seem to be important instruments but should be used with care. Policymakers should trade off the potential benefits and costs associated with CDSs trading, and firms should design the right incentive structures to activate the positive effect of CDSs on corporate innovation. In addition, our findings have important policy and practical implications for policymakers when promoting sustainable innovation investments in the economy. Whether the aggregate welfare of CDS trading is positive or negative is under debate. Besides the existing studies, future research needs to conduct thorough investigation into the potential effects of CDSs trading from other aspects of firms' activities. They might study the impact of CDS trading on corporate voluntary information disclosure and strategy making.

Author Contributions: Conceptualization, Y.C.; data curation, Y.C.; formal analysis, Y.C.; funding acquisition, J.Z.; project administration, J.Z.; writing—original draft, Y.C.; writing—review and editing, Y.C. and J.Z.

Funding: This work was supported by the National Science Foundation of China [71472148].

Conflicts of Interest: The authors declare no conflict of interest. 


\section{Appendix A}

Table A1. Draft Terms-Credit Default Swaps

\begin{tabular}{ll}
\hline 1. General Terms & \\
\hline Trade Date & August 5, 2003 \\
Effective Date & August 6,2003 \\
Scheduled Termination Date & July 30, 2005 \\
Floating Rate Payer ('Seller') & XYZ Bank plc, New York branch \\
Fixed Rate Payer ('Buyer') & ABC Investment Bank plc \\
Calculation Agent & Seller \\
Calculation Agent City & New York \\
Business Day & New York \\
Business Day Convention & Following \\
Reference Entity & XXX Corporation \\
Reference Obligation & Primary Obligor: XXX Corporation \\
Maturity & June 30, 2020 \\
Coupon & $0 \%$ \\
CUSIP/ISIN & XXXXX \\
Original Issue Amount & USD 100,000,000 \\
Reference Price & $100 \%$ \\
All Guarantees & Not Applicable \\
\hline 2. Fixed Payments & \\
\hline Fixed Rate Payer & ABC Investment Bank plc \\
Calculation Amount & USD 7,000,000 \\
Fixed Rate & $0.3 \%$ per annum \\
Fixed Rate Payer Payment Date(s) & October 30, January 30, April 30, July 30, \\
& starting October 30, 2003 \\
Fixed Rate Day Count Fraction & Actual/360 \\
\hline 3. Floating Payments & \\
\hline Floating Rate Payer & XYZ Bank plc, New York branch \\
Calculation Amount & USD 7,000,000 \\
Conditions to Payment (Or Seller) & Credit Event Notice \\
Credit Events & Bankruptcy Failure to Pay (Grace Period \\
& Extension: Not Applicable. Payment \\
Obligation(s) & Requirement: $\$ 1,000,000$ ) \\
\hline & Borrowed money \\
\hline & \\
\hline & \\
\hline
\end{tabular}


Table A1. Cont.

\section{General Terms}

4. Settlement Terms

Settlement Method

Settlement Currency

Terms Relating to Physical Settlement

Physical Settlement Period

Portfolio

Deliverable Obligations

Deliverable Obligation

Characteristics

Restructuring Maturity Limitation

Partial Cash Settlement of Loans

Partial Cash Settlement of Assignable Loans

Physical Settlement

The currency in which the Floating Rate

Payer Calculation Amount is denominated

The longest of the number of business days for settlement in accordance with the then-current market practice of any Deliverable Obligation being Delivered in the Portfolio, as determined by the Calculation Agent, after consultation with the parties, but in no event shall be more than 30 days

Exclude Accrued Interest

Bond or Loan

Not Subordinated

Specified Currency-Standard Specified

Currencies

Maximum Maturity: 30 years

Not Contingent

Not Bearer

Transferable

Assignable Loan

Consent Required Loan

Not Applicable

Not Applicable

Applicable

Escrow

\section{Documentation}

Confirmation to be prepared by the Seller and agreed to by the Buyer. The definitions and provisions contained in the 2003 ISDA Credit Derivatives Definitions, as published by the International Swaps and Derivatives Association, Inc., as supplemented by the May 2003 Supplement, to the 2003 ISDA Credit Derivatives Definitions (together, the "Credit Derivatives Definitions"), are incorporated into the Confirmation

\section{Notice and Account Details}

\begin{tabular}{ll} 
Telephone, Telex and/or: & Buyer: \\
$\begin{array}{l}\text { Facsimile Numbers and Contact Details for } \\
\text { Notices }\end{array}$ & Phone: \\
& Fax: \\
Account Details of Seller & Seller: \\
& Phone: \\
\hline
\end{tabular}




\section{Appendix B}

Table A2. Summary Statistics and Variables Correlations.

\begin{tabular}{|c|c|c|c|c|c|c|c|c|c|c|c|c|c|c|c|}
\hline \multicolumn{16}{|c|}{ Panel A: Summary Statistics } \\
\hline & RDS & LnPatent & Debt & Debt_S & Debt_L & VegaT & VegaC & KZindex & Trading & LNTA & Tangibility & Profitabili & y МТВ & HHI & HHI2 \\
\hline $\mathrm{N}$ & 39,488 & 39,488 & 39,488 & 39,488 & 39,488 & 9884 & 9884 & 37,058 & 39,488 & 39,488 & 39,488 & 39,488 & 39,488 & 39,488 & 39,488 \\
\hline Mean & 0.06 & 0.51 & 0.21 & 0.04 & 0.17 & 34.52 & 168 & -7.94 & 0.03 & 5.85 & 0.26 & -0.01 & 2.15 & 0.22 & 0.08 \\
\hline SD & 0.13 & 1.07 & 0.24 & 0.1 & 0.21 & 54.09 & 261.5 & 24.43 & 0.17 & 2.09 & 0.23 & 0.32 & 2.56 & 0.17 & 0.14 \\
\hline P25 & 0 & 0 & 0.01 & 0 & 0 & 1.93 & 23.03 & -6.24 & 0 & 4.33 & 0.07 & -0.03 & 1.11 & 0.1 & 0.01 \\
\hline Median & 0 & 0 & 0.16 & 0.01 & 0.1 & 13.96 & 70.69 & -1.14 & 0 & 5.74 & 0.18 & 0.06 & 1.52 & 0.17 & 0.03 \\
\hline P75 & 0.07 & 0.69 & 0.33 & 0.04 & 0.27 & 41.76 & 190 & 0.91 & 0 & 7.27 & 0.38 & 0.11 & 2.35 & 0.28 & 0.08 \\
\hline \multicolumn{16}{|c|}{ Panel B: Pearson and Spearman Correlations } \\
\hline RDS & & 0.379 & -0.276 & -0.100 & -0.285 & 0.127 & 0.125 & -0.340 & -0.030 & -0.121 & -0.371 & -0.079 & 0.280 & -0.094 & -0.094 \\
\hline LnPatent & 0.145 & & -0.043 & -0.006 & -0.044 & 0.197 & 0.140 & -0.117 & 0.051 & 0.153 & -0.136 & -0.073 & 0.084 & 0.003 & 0.003 \\
\hline Debt & -0.202 & -0.042 & & 0.465 & 0.954 & 0.074 & 0.043 & 0.504 & 0.112 & 0.380 & 0.297 & -0.156 & -0.344 & 0.036 & 0.036 \\
\hline Debt_S & -0.077 & -0.026 & 0.399 & & 0.281 & 0.072 & 0.070 & 0.199 & 0.093 & 0.275 & 0.148 & -0.025 & -0.166 & 0.069 & 0.069 \\
\hline Debt_L & -0.197 & -0.037 & 0.895 & -0.009 & & 0.075 & 0.041 & 0.511 & 0.121 & 0.375 & 0.316 & -0.156 & -0.341 & 0.031 & 0.031 \\
\hline VegaT & 0.043 & 0.229 & 0.025 & 0.055 & 0.012 & & 0.760 & -0.152 & 0.270 & 0.567 & -0.049 & 0.152 & 0.165 & -0.008 & -0.008 \\
\hline VegaC & 0.038 & 0.165 & 0.023 & 0.063 & 0.006 & 0.719 & & -0.149 & 0.251 & 0.464 & -0.052 & 0.160 & 0.177 & 0.010 & 0.010 \\
\hline KZindex & -0.148 & 0.006 & 0.179 & 0.053 & 0.180 & -0.006 & -0.035 & & -0.035 & 0.127 & 0.624 & -0.248 & -0.390 & -0.057 & -0.057 \\
\hline Trading & -0.056 & 0.072 & 0.061 & -0.022 & 0.081 & 0.289 & 0.252 & 0.011 & & 0.363 & 0.038 & -0.004 & -0.073 & 0.075 & 0.075 \\
\hline LNTA & -0.204 & 0.241 & 0.212 & -0.082 & 0.285 & 0.500 & 0.472 & 0.110 & 0.324 & & 0.186 & 0.016 & -0.138 & 0.050 & 0.050 \\
\hline Tangibility & -0.289 & -0.084 & 0.299 & 0.020 & 0.333 & -0.030 & -0.038 & 0.292 & 0.037 & 0.218 & & 0.019 & -0.176 & -0.130 & -0.130 \\
\hline Profitabilit & $y-0.370$ & 0.025 & -0.021 & -0.131 & 0.048 & 0.117 & 0.138 & 0.007 & 0.056 & 0.325 & 0.069 & & 0.560 & 0.027 & 0.027 \\
\hline MTB & 0.223 & 0.038 & -0.102 & -0.034 & -0.114 & 0.076 & 0.120 & -0.160 & -0.036 & -0.124 & -0.137 & -0.154 & & -0.061 & -0.061 \\
\hline HHI & -0.103 & 0.004 & -0.033 & 0.013 & -0.042 & 0.009 & 0.030 & 0.000 & 0.045 & -0.025 & -0.143 & 0.034 & -0.049 & & 1.000 \\
\hline HHI2 & -0.077 & 0.013 & -0.026 & 0.007 & -0.031 & 0.021 & 0.040 & 0.001 & 0.042 & -0.014 & -0.096 & 0.028 & -0.041 & 0.945 & \\
\hline
\end{tabular}

Note: This table presents summary statistics and variables correlations. Panel A reports summary statistics of main variables. Panel B reports the correlations among main variables used in the empirical analyses. Lower-triangular cells report Pearson's correlation. Upper-triangular cells are Spearman's rank correlation. Bolded coefficients indicate significance below the $1 \%$ level. RDS, research and development expenses of firm $\mathrm{i}$ in year $\mathrm{t}$ scaled by its total sales in year $\mathrm{t}$. LnPatent, the natural logarithm of one plus patent count of firm $\mathrm{i}$ in year t. Debt, defined as total liabilities plus preferred stock minus deferred taxes and convertible debt divided by total book assets at the end of year t. Debt_S, measured as short-term debt divided by total book assets at the end of year t. Debt_L, measured as long-term debt divided by total book assets at the end of year $\mathrm{t}$. VegaT, (Black-Scholes Vega of all current option grants + Black-Scholes Vega of all prior option grants $) \times 0.01$. VegaC, Black-Scholes Vega of all current option grants $\times 0.01$. KZindex, KZindex $=-1.001909 \times($ ib + dp)/lagged ppent $+0.2826389 \times($ at + prcc_f $\times$ csho-ceq-txdb)/at $+3.139193 \times(\mathrm{dltt}+\mathrm{dlc}) /(\mathrm{dltt}+\mathrm{dlc}+\mathrm{seq})-39.3678 \times(\mathrm{dvc}+\mathrm{dvp}) /$ lagged ppent $-1.314759 \times$ che/lagged ppent. Trading, equals 1 if firm i has active CDS trading by year $t$, and 0 otherwise. LNTA, measured as the natural log of total assets at the end of year t. Tangibility, measured as Net property, plant, and equipment of firm $\mathrm{i}$ in year $\mathrm{t}$ divided by its Total Assets in $\mathrm{t}$. Profitability, calculated as earnings before interest, depreciation, taxes, and amortization of firm $\mathrm{i}$ in year $\mathrm{t}$ divided by total assets in year $\mathrm{t}$. MTB, defined as total assets plus market value of common equity minus book equity all over total assets at the end of year $\mathrm{t}$. HHI, sales based Herfindahl index of four-digit SIC industry $j$ to which firm i belongs, measured at the end of year $\mathrm{t}$. HHI2, The squared term of HHI. 


\section{References}

1. Erkut, B. The emergence of the ERP software market between product innovation and market shaping. J. Open Innov. Technol. Mark. Complex. 2018, 4, 23. [CrossRef]

2. Witt, U. Firms as realizations of entrepreneurial visions. J. Manag. Stud. 2007, 44, 1125-1140. [CrossRef]

3. Porter, M. Capital disadvantage: America's failing capital investment system. Harv. Bus. Rev. 1992, 70, 65-82. [PubMed]

4. Romer, P. Increasing returns and long-run growth. J. Political Econ. 1986, 94, 1002-1037. [CrossRef]

5. Hall, B.H.; Lerner, J. The financing of innovation. In Handbook of the Economics of Innovation; Bronwyn, H.H., Nathan, R., Eds.; North-Holland: Amsterdam, The Netherlands, 2010; pp. 609-639.

6. Brown, J.R.; Fazzari, S.M.; Petersen, B.C. Financing innovation and growth: Cash flow, external equity, and the 1990s R\&D boom. J. Financ. 2009, 64, 151-185.

7. Hall, B.H. The financing of research and development. Oxf. Rev. Econ. Policy 2002, 18, 35-51. [CrossRef]

8. Blanchard, O. Public debt and low interest rates. Am. Econ. Rev. 2019, 109, 1197-1229. [CrossRef]

9. Fischer, T.; Ringler, P. What patents are used as collateral?-An empirical analysis of patent reassignment data. J. Bus. Ventur. 2014, 29, 633-650. [CrossRef]

10. William, M. Creditor rights and innovation: Evidence from patent collateral. J. Financ. Econ. 2018, 130, $25-47$.

11. Atanassov, J. Do hostile takeovers stifle innovation? Evidence from antitakeover legislation and corporate patenting. J. Financ. 2013, 68, 1097-1131. [CrossRef]

12. Jarrow, R.A. The economics of credit default swaps. Annu. Rev. Financ. Econ. 2011, 3, 235-257. [CrossRef]

13. Augustin, P.; Subrahmanyam, M.G.; Tang, D.Y.; Wang, S.Q. Credit default swaps: A survey. In Foundations and Trends in Finance; Now Publishers: Hanover, MA, USA, 2014; Volume 9, pp. 1-196.

14. Bolton, P.; Oehmke, M. Credit default swaps and the empty creditor problem. Rev. Financ. Stud. 2011, 24, $2617-2655$. [CrossRef]

15. Augustin, P.; Subrahmanyam, M.G.; Tang, D.Y.; Wang, S.Q. Credit default swaps: Past, present, and future. Annu. Rev. Financ. Econ. 2016, 8, 175-196. [CrossRef]

16. Lélé, S.M. Sustainable development: A critical review. World Dev. 1991, 19, 607-621. [CrossRef]

17. Dixon, J.A.; Fallon, L.A. The concept of sustainability: Origins, extensions, and usefulness for policy. Soc. Nat. Resour. 1989, 2, 73-84. [CrossRef]

18. Barbier, E.B. The concept of sustainable economic development. Environ. Conserv. 1987, 14, 101-110. [CrossRef]

19. Romer, P. Endogenous technological change. J. Political Econ. 1990, 98, 71-101. [CrossRef]

20. Aghion, P.; Howitt, P.A. Model of growth through creative destruction. Econometrica 1992, 60, 323-351. [CrossRef]

21. Porter, M.E. The Competitive Advantage of Nations; Free Press: New York, NY, USA, 1990.

22. Barney, J. Firm resources and sustained competitive advantage. J. Manag. 1991, 17, 99-120. [CrossRef]

23. Yoo, J.; Lee, S.; Park, S. The effect of firm life cycle on the relationship between R\&D expenditures and future performance, earnings uncertainty, and sustainable growth. Sustainability 2019, 11, 2371.

24. Loredo, E.; Lopez-Mielgo, N.; Pineiro-Villaverde, G.; García-Álvarez, M.T. Utilities: Innovation and sustainability. Sustainability 2019, 11, 1085. [CrossRef]

25. Modigliani, F.; Miller, M.H. The cost of capital, Corporation finance and the theory of investment. Am. Econ. Rev. 1958, 48, 261-297.

26. Masulis, R.W. The effects of capital structure change on security prices: A study of exchange offers. J. Financ. Econ. 1980, 8, 139-178. [CrossRef]

27. Dann, L.Y. Common stock repurchases: An analysis of returns to bondholders and stockholders. J. Financ. Econ. 1981, 9, 113-138. [CrossRef]

28. Masulis, R.W.; Korwar, A.N. Seasoned equity offerings: An empirical investigation. J. Financ. Econ. 1986, 15, 91-118. [CrossRef]

29. Pinegar, J.M.; Lease, R.C. The impact of preferred-for-common exchange offers on firm value. J. Financ. 1986, 41, 795-814. [CrossRef]

30. Graham, J.R.; Harvey, C.R. The theory and practice of corporate finance: Evidence from the field. J. Financ. Econ. 2001, 60, 187-243. [CrossRef] 
31. Arzac, E.R.; Glosten, L.R. A reconsideration of tax shield valuation. Eur. Financ. Manag. 2005, 11, $453-461$. [CrossRef]

32. Taleb, N.N. Antifragile: Things That Gain From Disorder; Random House Incorporated: New York, NY, USA, 2012.

33. Williamson, O.E. Corporate finance and corporate governance. J. Financ. 1988, 43, 567-591. [CrossRef]

34. Rajan, R.G. Has finance made the world riskier? Eur. Financ. Manag. 2006, 12, 499-533. [CrossRef]

35. Stout, L.A. Regulate OTC derivatives by deregulating them. Regulation 2009, 32, 30-41.

36. Soros, G. One Way to Stop Bear Raids: Credit Default Swaps Need Much Stricter Regulation. The Wall Street Journal, 24 March 2009.

37. Stulz, R. Credit default swaps and the credit crisis. J. Econ. Perspect. 2010, 24, 73-92. [CrossRef]

38. Culp, C.L.; Andria, V.D.M.; Staerkle, B. Single-Name Credit Default Swaps: A Review of the Empirical Academic Literature; Working paper; ISDA: New York, NY, USA, 2016.

39. Hu, H.T.C.; Black, B. Debt, equity and hybrid decoupling: Governance and systemic risk implications. Eur. Financ. Manag. 2008, 14, 663-709. [CrossRef]

40. Saretto, A.; Tookes, H.E. Corporate leverage, debt maturity, and credit supply: The role of credit default swaps. Rev. Financ. Stud. 2013, 26, 1190-1247. [CrossRef]

41. Martin, X.; Roychowdhury, S. Do financial market developments influence accounting practices? Credit default swaps and borrowers' reporting conservatism. J. Account. Econ. 2015, 59, 80-104. [CrossRef]

42. Chen, W.R.; Miller, K.D. Situational and institutional determinants of firms' R\&D search intensity. Strateg. Manag. J. 2007, 28, 369-381.

43. Hirshleifer, D.; Low, A.; Teoh, S.H. Are overconfident ceos better innovators? J. Financ. 2012, 67, 1457-1498. [CrossRef]

44. Fang, V.W.; Tian, X.; Tice, S. Does stock liquidity enhance or impede firm innovation? J. Financ. 2014, 69, $2085-2125$. [CrossRef]

45. Hall, B.H.; Jaffe, A.B.; Trajtenberg, M. The NBER patent citation data file: Lessons, insights and methodological tools. Natl. Bur. Econ. Res. 2014. [CrossRef]

46. Griliches, Z.; Hall, B.H.; Pakes, A. R\&D, patents, and market value revisited. Econ. Innov. New Technol. 1991, 1, 183-201.

47. Ashcraft, A.; Santos, J. Has the CDS market lowered the cost of corporate debt? J. Monet. Econ. 2009, 56, 514-523. [CrossRef]

48. Subrahmanyam, M.G.; Tang, D.Y.; Wang, S.Q. Does the tail wag the dog? The effect of credit default swaps on credit risk. Rev. Financ. Stud. 2014, 27, 2927-2960. [CrossRef]

49. Subrahmanyam, M.G.; Tang, D.Y.; Wang, S.Q. Credit default swaps, exacting creditors and corporate liquidity management. J. Financ. Econ. 2017, 124, 395-414. [CrossRef]

50. Atanassov, J. Arm's length financing and innovation: Evidence from publicly traded firms. Manag. Sci. 2015, 62, 128-155. [CrossRef]

51. Ziedonis, R.; Hall, B.H. The effects of strengthening patent rights on firms engaged in cumulative innovation: Insights from the semiconductor industry. In Entrepreneurial Inputs and Outcomes: New Studies of Entrepreneurship in the United States; Emerald Group Publishing Limited: Bingley, UK, 2001; pp. 133-187.

52. Aghion, P.; Bloom, N.; Blundell, R.; Griffith, R.; Howitt, P. Competition and innovation: An inverted-U relationship. Q. J. Econ. 2005, 120, 701-728.

53. Petersen, M.A. Estimating standard errors in finance panel data sets: Comparing approaches. Rev. Financ. Stud. 2009, 22, 435-480. [CrossRef]

54. Aiken, L.S.; West, S.G.; Reno, R.R. Multiple Regression: Testing and Interpreting Interactions; Sage: Thousand Oaks, CA, USA, 1991.

55. Stohs, M.H.; Mauer, D.C. The determinants of corporate debt maturity. J. Bus. 1996, 69, 279-312. [CrossRef]

56. Ozkan, A. An empirical analysis of corporate debt maturity structure. Eur. Financ. Manag. 2000, 6, $197-212$. [CrossRef]

57. Core, J.; Guay, W. Estimating the value of employee stock option portfolios and their sensitivities to price and volatility. J. Account. Res. 2002, 40, 613-630. [CrossRef]

58. Hayes, R.M.; Lemmon, M.; Qiu, M. Stock options and managerial incentives for risk taking: Evidence from FAS 123R. J. Financ. Econ. 2012, 105, 174-190. [CrossRef]

59. Kaplan, S.N.; Zingales, L. Do investment-cash flow sensitivities provide useful measures of financing constraints? Q. J. Econ. 1997, 112, 169-215. [CrossRef] 
60. Adam, T. Capital expenditures, financial constraints, and the use of options. J. Financ. Econ. 2009, 92, $238-251$. [CrossRef]

61. Bangia, A.; Diebold, F.X.; Kronimus, A.; Schagen, C.; Schuermann, T. Ratings migration and the business cycle, with application to credit risk portfolio stress testing. J. Bank. Financ. 2002, 26, 445-474. [CrossRef]

62. Kerr, W.R.; Nanda, R. Financing Innovation; Working paper; NBER: Cambridge, MA, USA, 2014.

63. Robb, A.M.; Robinson, D.T. The capital structure decisions of new firms. Rev. Financ. Stud. 2014, $27,153-179$. [CrossRef]

64. Chang, X.; Chen, Y.; Wang, S.Q.; Zhang, K.; Zhang, W. Credit default swaps and corporate innovation. J. Financ. Econ. 2019, in press. [CrossRef]

(C) 2019 by the authors. Licensee MDPI, Basel, Switzerland. This article is an open access article distributed under the terms and conditions of the Creative Commons Attribution (CC BY) license (http://creativecommons.org/licenses/by/4.0/). 